\title{
Biyosanat: Selin Balcı ve Ayşe Gül Süter'in Biyosanat Projelerinin İncelenmesi
}

\section{Bioart: Investigation of Selin Balcı and Ayşe Gül Süter's Bioart Projects}

Elif Çakıroğlu, Güzel Sanatlar Eğitimi Bölümü, Pamukkale Üniversitesi

\begin{abstract}
Özet
Bilim ve sanatın etkileşiminden doğan biyosanat, biyoteknoloji, genetik ve moleküler biyoloji gibi çalışma alanlarıyla enstalasyon, performans, video ve süreç sanatı gibi çağdaş sanat pratiklerinin iç içe geçtiği uygulamalardan olușmaktadır. Biyosanat, özellikle canlılarla ilgili bilimsel gelişmelere ve teknolojinin bir araç olarak sınırlarına yönelik farkındalığa katkı sağlamaktadır. Calıșmada biyosanat alanında çalışmalar yapan Selin Balcı'nın Kontaminasyon Serisi, Bordered World ve 200; Ayșe Gül Süter'in Tear Drop Crystals ve Crystals In An Artist's Studio adlı biyosanat projelerinin, sanatçıların kişisel web sitelerinde yer verdikleri açıklamaları doğrultusunda incelenmesi amaçlanmıştır. Bu amaçla biyosanata ilişkin literatür taraması yapılmıș ve dünyada öne çıkan biyosanat projeleri açıklanmıştır. Sonuç olarak çalışmanın amacı kapsamında ilgili literatür ıșığında incelenen Selin Balcı ve Ayșe Gül Süter'in biyosanat projelerinin doğaya ve yaşama yönelik farklı bakış açısı sundukları görülmüștür. Ayrıca projelerinde sanatsal anlatımlarının bir parçası olan mikroorganizmalar ya da kristaller gibi biyolojik materyalleri birer metafor olarak kullandıkları ve böylelikle insanların psikobiyososyal etkinliklerine göndermelerde bulundukları anlașılmıștır. Söz konusu projelerin incelenerek yorumlanması, bilim, sanat ve teknolojiyi birleștiren biyosanata yönelik ilgi uyandırmak ve bilimsel okuryazarlığın gelișimine katkı sağlamak açısından önemli görülmektedir.
\end{abstract}

Anahtar Sözcükler: Biyosanat, yeni medya sanatı, çağdaş sanat, Selin Balcı, Ayșe Gül Süter.

Akademik disipin(ler)/alan(lar): Güzel Sanatlar, yeni medya sanatı, çağdaş sanat.

\begin{abstract}
A bioart consists of intertwined applications in which fields of study such as biotechnology, genetics and molecular biology and contemporary art practices such as installation, performance, video and process art. Bioart contributes to the awareness of scientific developments and the limitations of technology as a tool, especially about living things. In the study, It is aimed to analyze Selin Balcı's Contamination Series, Bordered World and 200 and Ayşe Gül Süter's bioart projects Tear Drop Crystals and Crystals In An Artist's Studio in line with the explanations of the artists on their personal websites. For this purpose, a literature review on bioart was made and prominent bioart projects in the world were explained. As a result, it was seen that Selin Balcı and Ayșe Gül Süter, who were examined in the light of the relevant literature within the scope of the study, presented different perspectives on nature and life in their bioart projects. In addition, it has been understood that they use biological materials such as microorganisms or crystals, which are a part of their artistic expression, as metaphors, in their projects and thus make references to human's psychobiosocial activities. Analyzing and interpreting of the projects is considered important in terms of arousing interest in bioart that combines science, art and technology and contributing to the development of scientific literacy.
\end{abstract}

Keywords: Bioart, new media art, contemporary art, Selin Balcı, Ayşe Gül Süter.

Academical disciplines/fields: Fine Arts, New Media Art, Contemporary Arts.

- Sorumlu Yazar: Elif Çakıroğlu, Güzel Sanatlar Eğitimi Bölümü, Eğitim Fakültesi, Pamukkale Üniversitesi.

- Adres: Pamukkale Üniversitesi Eğitim Fakültesi Resim-İş Eğitimi Anabilim Dalı Kınıklı Kampüsü/Denizli.

- $\quad$ e-posta: eliphcakiroglu@gmail.com

- ORCID: 0000-0003-1516-7527

- Cevrimiçi yayın tarihi: 08.06 .2021

- doi: $10.17484 /$ yedi.899356 


\section{Giriş}

Bilim, teknoloji ve sanatı birleștiren biyosanat, çağdaș sanat yaklașımları içinde yer almaktadır. Çağdaș sanatın başlangıcı ise 1960'ların ilk yıllarındadır: Performans, minimalizm ve kavramsal sanat olmak üzere bir dizi yeni eser türünün, genel kabul gören nesne-temelli ve neo-avangard pratiklerden ontolojik olarak koptuğu andadır. Bu bakış açısına göre, çağdaş sanat, kavramsalcılık-sonrası sanattır (Osborne, 2017). 1960’lı yıllarda sanat ortamında yaşanan belki de en büyük dönüşüm, sanatın nesneye olan gereksiniminin tartışılmaya açılmasıdır. Estetik hazlardan ziyade düşüncenin ön plana geçtiği bir sanat pratiğinin etkilerinin yoğun bir biçimde hissedilmeye başlamasıyla, yapıtın maddi varlığı ve biçimi büyük ölçüde etkisini yitirmiştir. Bu özellikleri taşıyan yeni eğilimler, minimalist sanatçı Sol Lewit'in kendi yapıtlarının kavramsallığını vurgulamak için 1967 yılında ArtForum dergisinde yayınladığı Kavramsal Sanat Üzerine Paragraflar yazısından sonra kavramsal sanat başlı̆̆ altında toplanmıștır (Antmen, 2010, s. 193). Kavramsal sanat, resim ve heykel geleneğinin dıșında kalan her türlü alternatif sanat biçimlerini niteleyen genel bir terim olmuştur (Atakan, 2008, s. 13). Sanatçlların bedenini kullanarak gerçekleştirdiği performans ya da happening (oluşum) türünde gösteriler, enstalasyon ya da çevre düzenlemeleriyle doğada gerçekleştirilen arazi, toprak, çevre sanatı türünde projeler ve benzeri sanatsal ifadeler, izleyiciyi estetikten önce zihinsel bir algılama sürecine çağırması bakımından kavramsal sanat içerisinde değerlendirilebilmektedir (Antmen, 2010, s. 193). Mitchell'e göre canlılı̆̆ 1 ve sistemlerini sanatsal konular olarak ele alan, bilimsel ve teknolojik unsurları sanatsal teknik olarak kullanan biyosanatın, yeni bir sanat türü olmaktan çok yeni bir kavramsal sanat tarzı olarak anlaşılması gerekmektedir. Yani, bir fikir ya da kavrama işaret etmek için belirli medya türü olan sanat nesnesiyle estetik açıdan daha az ilgilenen bir sanat geleneğinin parçasıdır. Bu açıdan bakıldığında biyosanat içerisinde değerlendirilen çeşitli sanat eserleri, biyoteknoloji hakkında eleştirel tartışma yaratmaya ilgi duymaktadır (Mitchell, 2010, s. 23). Biyosanat, doğada yer alan biyolojik yeni sanat medyasıyla içi içe geçen birçok geleneksel sanat medyasının kullanımını içeren ve gelişmekte olan çağdaş bir sanat uygulamasıdır. Buna ek olarak genetik, büyüme, hücre bölünmesi ve fotosentez gibi biyolojik süreçleri; yaşamın ve evrimin kökeni gibi kavramları kullanarak kavramsal sanata genişlemektedir ve bunları yeni sanat medyası olarak açıklamaktadır (Melkozernov ve Sorensen, 2020, s. 1). Biyosanat, çoğunlukla yapıt ve izleyici etkileşimine imkân sağlayan enstalasyon, performans, video sanatı, süreç sanatı ve benzeri gibi çağdaş sanat biçimleriyle birlikte kurgulanarak sergilenmektedir. Böylece merak uyandırıcı ve etkileyici özelliği pekişmektedir. Aynı zamanda biyosanat projeleri, sergiler, konferanslar, sempozyumlar ve atölyeleri birleștiren daha geniş bir etkinliğin parçasıdır ve genellikle bu etkinliklere yeni medya sanatı ile sanat ve bilimlerin kesiştiği bir geleneğe veya ilgiye sahip enstitüler ev sahipliği yapmaktadır (Kallergi, 2008).

Çalışmada öncelikle biyolojik materyallerden oluşan yeni medya sanatını çağdaş sanat pratikleri aracılığıyla ortaya koyan biyosanata ilişkin literatür taraması yapılarak öne çıkan biyosanat çalışmaları açıklanmıştır. Ayrıca ülkemizde henüz çok yeni olan biyosanat alanında çalışmalar yapan Selin Balcı'nın Kontaminasyon Serisi, Bordered World ve 200 adını verdiği biyosanat projeleri; Ayşe Gül Süter'in Tear Drop Crystals ve Crystals In An Artist's Studio adlı biyosanat projeleri, kişisel web sitelerinde yer verdikleri açılamaları doğrultusunda incelenmiştir. Çağdaş dünyadaki bilimsel gelişmeleri yansıtan uluslararası boyutta tanınan biyosanat uygulamalarının ve ülkemizin birer değeri olan sanatçların biyosanat projelerinin incelenmesi, sanatsal ve bilimsel gelişmelere yönelik ilgi ve farkındalık geliştirmek açısından önemli görülmektedir.

\section{Yaşayan Sistemlerle Sanat: Biyosanat nedir?}

Biyosanat, yaşayan sistemleri sanatsal konular olarak keşfetmek için bilimsel yöntemleri ve biyoteknolojiyi araç edinen çağdaş bir sanat formudur (Yetişen, Davis, Coşkun, Church ve Yun, 2015, s. 724). Biyosanat, 1980'lerde ortaya çıkmıștır ve 2000'lerde gelişerek küresel bir ölçekte yayılıp genişlemiştir (Vaage, 2016, s. 23). Biyoteknolojinin sanatsal kullanımını içerir, çünkü biyosanatçılar hem yaşayan sanat eserlerini yaratmak hem de bu varlıkları bir sanat galerisi alanında canlı tutmak için biyolojik laboratuar tekniklerini ve teknolojilerini kullanmaktadırlar. Biyosanatı diğer sanat biçimlerinden ayıran şey, aslında, biyomühendislik yaşamını sanatsal bir araç olarak kullanma iddiasıdır. Daha önceki sanat formları yağlı ve akrilik boya, jelatin gümüş baskılar (fotoğraf), taş veya çelik gibi ortamları kullanırken biyosanat eserleri, bakteri, klonlanmış ağaçlar veya sanatçının vücut dokusu, fare hücreleri, sığır hücresel matrisi ve hücre ortamı gibi ortamları kullanmaktadır (Mitchell, 2010, s. 5). Buna ek olarak biyosanat eserleri, canlı ve cansız, organik ve inorganik unsurlar arasındaki sınır meselelerini araștırmaktadır. Yaşamın özü hakkında ne kadar az soru sorulduğunu vurgulamaktadır ve yaşamın içindeki süreçsel ve kontrol edilemez olanı keşfederek sahneye koymaktadır. Böylece materyal ve kavramsal sınırları aşmaktadır. Biyosanat 
aracılığıyla ortaya çıkan projeler, yaşamın ontolojisine odaklanmaktadır (Radomska, 2016, s. 13-14). Disiplinlerarası biyosanat girişimleri, felsefi, toplumsal ve çevresel konulara vurgu yaparak sanat ve modern biyoloji arasındaki sınırları bulanıklaștırmaktadır. Aynı zamanda ortaya çıkan yașam bilimi uygulamalarına eleștirel bir meydan okuma, bilimsel düşünceyi teşvik etme, yeni araştırma sorularına ve yeni teknolojilere katkı sunma konusunda önemli bir rol oynamaktadır (Yetişen vd., 2015, s. 724). Biyosanat, sanatçı, bilim, halk ve biyolojik organizma ya da biyolojik kavramlar arasındaki ilişkileri içeren düşünce ve duyguları iletmektedir (Melkozernov ve Sorensen, 2020, s. 1). Bazı biyosanatçılar, bilim insanlarıyla iş birliği içinde kamusal tartışmalara imkân veren ifadeleri yaratmak için biyolojik yöntemleri uygulamaktadırlar. Biyoteknolojik eserlerin bazıları ise, genetik mühendisliğinin bazı riskleri hakkında rahatsız edici senaryolar olușturma amacıyla izleyiciye sunulmaktadır (Yetișen vd., 2015, s. 724). Böylelikle insanlığı, doğayı ve tüm canlıları ilgilendiren biyoteknik gelişmelere yönelik farkındalık geliștirmek hedeflenmektedir. Biyosanat çalıșmaları yapan Eduardo Kac, George Gessert, Marion Laval-Jeantet, Benoît Mangin, Marta de Menezes, Paul Vanouse tarafından hazırlanan ve Kac'a ait web sitesinde yayınlanan manifestoya göre biyosanatın özellikleri şöyledir:

- Biyolojik manipülasyon süreçlerinde biyosanat, doğrudan yaşam ağlarına müdahale etmektedir.

- Hayatın, diğer medyalara indirgenemeyen maddi bir özgüllüğü vardır.

- Doğrudan biyolojik müdahale olmaksızın, yalnızca akrilik, kâğıt, piksel, plastik, çelik veya herhangi bir cansız maddeden yapılmış sanat, biyosanat değildir.

- Tüm sanat malzemelerinin etik çıkarımları vardır, ancak bunlar en çok medya canlı olduğunda etkili olmaktadır. Biyosanat, insanlar ve insan olmayanlar açısından etik olmalıdır.

- Biyosanatın biyoloji veya yaşamla ilgili konuları tematik hale getirme yükümlülüğü yoktur.

- Biyosanat canlı olduğu için sanatçı tarafından açık edilsin ya da edilmesin, sanat izleyicilerinin biyosanatın politik, sosyal, kültürel ve etik çıkarımları olduğunu kabul etmelerine güvenmekteyiz.

- Biyosanat, insan ve insan olmayan, yaşayan ve cansız, doğal ve yapay arasındaki sınırlara meydan okumaktadır. (Kac vd., 2017)

Görüldüğü üzere manifestoda biyosanat materyalleri, etik, biyosanat ve izleyici ilişkisi gibi temel konulara değinilmiştir. Bunların dışında daha önce de belirtildiği gibi biyosanat, aktivist sanat, vücut sanatı (body art), enstalasyon sanatı veya ses sanatı ile iç içedir (Erçel, 2019, s. 62). Biyosanatın yer aldığı modern biyoloji ve biyoteknoloji ile sanat ve yeni medya arasındaki kesişimde, farklı katılım ve eleștiri stratejileri kullanılmaktadır. Bu da farklı teknik ve teknolojiler anlamına gelmektedir. Sanatçı ve bilim adamları arasında iş birliği içermektedir (Thacker, 2005, s. 307). Biyosanat, bilimsel gelişmelerin gerçekçi görüşleriyle birleştirilebildiği için insanları bilim hakkında bilgilendirmeye yardımcı olmaktadır. Biyoteknolojiye olan sanatsal tepkiler, siyasi aktivizme benzeyen kültürel yorumları da içermektedir. Bununla birlikte, sanat sadece tepkilerle ilgili değildir. Ayrıca yeni bilim ve mühendislik kavramları başlatabilir, iş birliğine teşvik edebilir, bilimsel okuryazarlığı artırabilir, sanatçıların biyoloji toplulukları ve yaşam bilimleriyle gelecekteki ilişkilerinin temelini oluşturmaya yardımcı olabilir (Yetişen vd., 2015, s. 724). Biyosanatçılar, insanlığın ve bilimin ilişkisini konu edinerek biyosanatı bilimdeki gelişmeleri aktarma aracı olarak kullanmışlardır. Bu alanda disiplinler arası akademiler, araştırma merkezleri ve laboratuvarlar kurulmuştur. Laboratuvarlar mekansal olarak deneysel üretim merkezlerine dönüşmüştür. Birçok biyosanatçı disiplinler arası programlarla çalışmış, sadece medya sanatı değil mühendislik bilimleri de kullanılmıştır. New York Görsel Sanatlar Okulu ve Biyosanat Laboratuvarı, Fin Biyo Sanat Topluluğu (Bioart Scoiety), SymbioticA biyosanat alanında kurulan önemli akademiler arasında sayılabilir (Erçel, 2019, s. 62).

\subsection{Biyosanatçılar ve Biyosanat Projeleri}

Biyosanat, nispeten yeni bir gelişmedir ve yeni tanımlanmaktadır. Ancak köken olarak iki modern yaratıcıyla ilișkilendirilebilir. Biri sanatçı Edward Steichen, diğeri ise bir bilim adamı ve penisilini keșfeden Alexander Flemingdir. Fotoğrafçı olan Steichen, mutasyon yoluyla çok kromozomluluğa neden olan ve toksin özellik gösteren kimyasal bir kolşisini (colchicine) delphinium tohumlarına uygulamıştır. Sonrasında 1936'da Modern Sanat Müzesi'nde bu kimyasal deney sonunda elde ettiği garip ama güzel Delphinium çiçeklerinden oluşan koleksiyonu sergilemiştir. Daha öncesinde ise 1933'te Alexander Fleming, bir sanat 
galerisinden ziyade bir hastanede de olsa mikrop resimlerini (kültür ortamında önceden ıslatılmış ve sonra inkübe edilmiş kâğıda bakteri koyarak çizilmiş görüntüler) elde ederek sergilemiștir (Stracey, 2009, s. 496). Öne çıkan diğer biyosanatçılar ise Eduardo Kac, Oran Catts, Ionat Zurr, Stelarc (Stelios Arcadiou), Joe Davis, Hunter Cole, Heather Dewey Hagborg gibi sanatçlardır.

Biyosanat çalışmaları içerisinde genetik yapısı değiştirilmiş (transgenik) formlar, doku kültürü mühendisliği ve hibrit canlılar da dahil olmak üzere biyoteknolojiyle ilişkili teknikler ve yaşam yaratan ya da yaşamı manipüle eden sanatçıların yer aldığı yeni ve gelişmekte olan bir alan olarak bir dizi biyosanat uygulaması bulunmaktadır (Byerley ve Chong, 2015, s. 201). Bu uygulamalardan dikkat çeken ve heyecan yaratan biyosanat projelerinden biri, Eduardo Kac' a ait GFP Bunny adlı projedir.

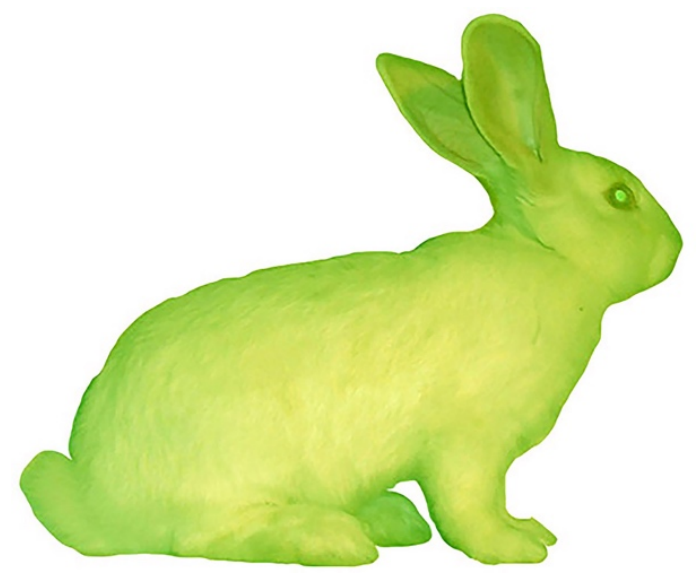

Şekil 1. GFP Bunny, E. Kac, 2000.

2000 yılında hayata geçirilen GFP Bunny adlı proje, Şekil 1'de görülen yeșil floresan bir tavşanın (Alba) yaratılmasını, proje tarafından oluşturulan kamusal diyaloğu ve tavşanın sosyal entegrasyonunu içermektedir (Kac, 2011). Projede, Aequorea Victoria türü bir denizanasında bulunan orijinal yeşil floresan geninin sentetik bir mutasyonla geliștirilmiş bir versiyonu olan EGFP yaratılmıştır. İnsan hücreleri dahil tüm memeli hücrelerinde EGFP, orijinal denizanası genininkinden yaklașık iki katı floresan vermektedir. Tavşanlar için zararsız olan yeşil floresan proteinin üretiminden sorumlu genetik sekans, zigot mikroenjeksiyonu yoluyla genoma entegre edilmiştir. Gebelik süreci başarıyla tamamlanmıştır. Uygulamalar sonrasında Alba adı verilen albino tavşan, mavi ışıkla (488 nanometrede maksimum uyarma ile) aydınlatıldığında yeșil ıșık ile parlayan bir tavşan haline gelmiștir. Kac, GFP Bunny projesinde uygulanan mikroenjeksiyon ve yeşil floresan protein teknolojilerinin moleküler biyoloji alanında zaten yapılmakta olan genetik bir deney biçimi olduğunu ve yeşil floresan proteinin tavşana zararsız olduğunu, GFP Bunny projesinin hiçbir sosyal kuralı çiğnemediğini belirtmiştir. Aynı zamanda insanların tavşanların evriminde en az 1.400 yıldır önemli bir rol oynadığını da eklemiştir (Kac, 2003, s. 97-100).

Kac, moleküler biyoloji alanında yapılan yeșil floresan proteinin mikroenjeksiyonunu içeren uygulamayı, GFP Bunny biyosanat projesinde gerçekleştirerek genetik alanında bilimsel yapılabilirliği görünür kılmıştır. Sanatçı, insanların, doğal ya da yapay yollarla doğanın ve diğer canlıların evrimsel sürecini etkilediğini belirterek genetik çalışmaların varacağı boyuta kamusal ilgi oluşturmuştur. Böylece GFP Bunny projesinin genetik bilimine ilişkin farkındalık sağladığı söylenebilir.

Bir diğer çalışma ise Tissue Culture and Art'ı (TC\&A) kuran Oron Catts ve Ioanat Zurr 'un çalışmasıdır. Catts ve Zurr, hücre tiplerinin araştırma ve tıpta kullanımı için biyolojik olarak parçalanabildiği ve yapı iskelesinde büyütüldüğü, rejeneratif tıp ve doku mühendisliği tekniklerini içeren projelerde uzmanlaşmışlardır (Yetișen vd., 2015, s. 731). 1996'da, doğal bedenlerin dişında tekno-bilimsel olarak bir petri kabı veya biyoreaktör aracılığıyla büyütülen ya da inşa edilen doku yapılarını tanımlamak için (semiliving) yarı canlı terimini kullanmaya başlayan Catts ve Zurr (2013a, s. 74), 2003 yılında Disembodied Cuisine projesini Fransa'nın Nantes kentindeki L'Art Biotech sergisinin bir parçası olarak gerçekleştirmiştir. Şekil 2'de görseline yer verilen Disembodied Cuisine adını taşıyan enstalasyon, neyin yenilebilir ve neyin iğrenç olduğuna dair farklı kültürel algılar üzerinde yoğunlaşmıştır. Projede yarı canlı (semi-living) kurbağa bifteği yetiştirilmiştir. Fransızların damak tadına ve tasarlanmış yiyeceklere karşı kızgınlıklarına ve diğer kültürlerin kurbağaların tüketimine yönelik itirazlarına alaycı bir bakış geliştirilmiştir. Projede kurbağa kası, potansiyel gıda tüketimi için biyopolimer üzerinde büyütülmüştür ve sağlılı kurbağalara 
enstalasyonun bir parçası olarak yer verilmiştir. Gösterinin son gününde biftek pişirilerek Nouvelle Mutfağı tarzında bir akşam yemeğinde yenilmiştir ve çiftlikten kurtarılan dört kurbağa yerel botanik bahçelerindeki güzel bir gölete bırakılmıştır (Catts ve Zurr, 2013b, s. 106).

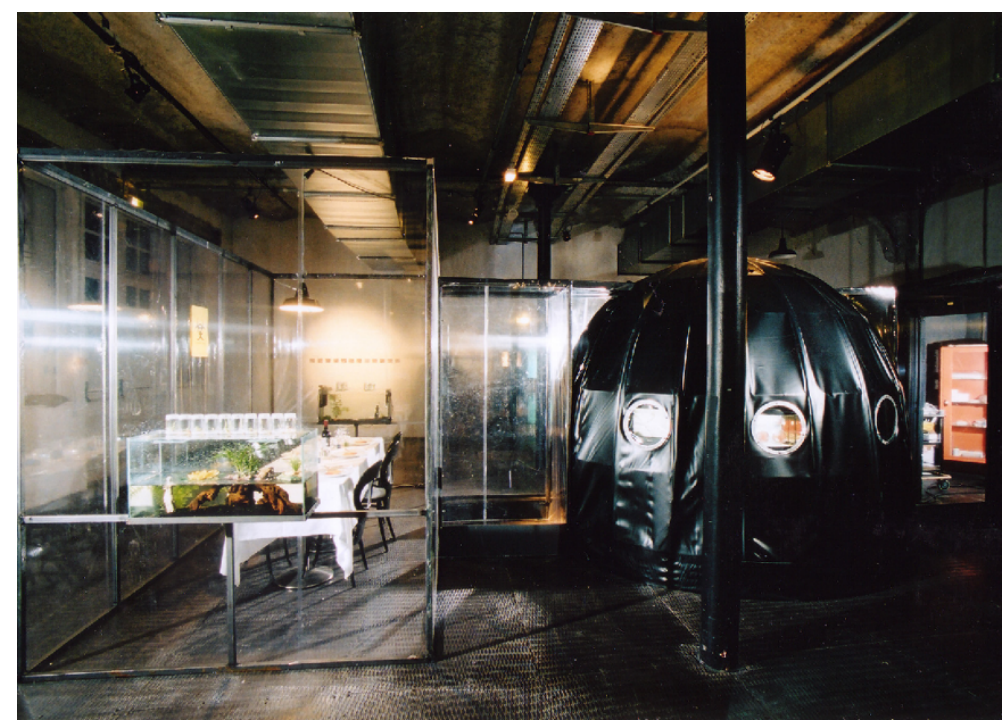

Șekil 2. Disembodied Cuisine, O. Catts, I. Zurr, 2003.

Catts ve Zurr tarafından gerçekleştirilen bir diğer proje de Şekil 3'te görülen Victimless Leather projesidir. Victimless Leather Projesi, 2004 yılında Avusturalya Perth'de yer alan John Curtin Gallery'de düzenlenen The Space Between adlı tekstil ve moda gösterisinde tanıtılmıștır (Sharma, 2014, s. 406). Proje, teknobilimsel bir vücutta yetiştirilen dikişsiz ceket prototipi sunmaktadır. Biyolojik olarak çözünebilen polimer matrisle desteklenen insan ve fare hücreleri karışımından oluşturulan canlı doku katmanlarından mont biçiminde minyatür deri üretilmiştir (Catts ve Zurr, 2006, s. 7). Projenin amacı, diğer canlıların sömürülmesi hakkında sorular sormaktır. Sanatçılar, proje kapsamında gelecekte yapılabilecek üretimlerin somut örneklerini sunmayı ve bu yeni üretim biçimlerinin kültürel algılarımız üzerindeki etkilerini araștırmayı hedeflemiştir (Catts ve Zurr, 2008, s. 34). Catts ve Zurr'a göre proje, kurbansız bir varoluş yanılsaması yaratmaktadır. Ancak in vitro (laboratuvar ortamında) et yetiştirebilmek için hayvanların kan plazmasının kullanıldığı bir seruma ihtiyaç duyulmaktadır. Bu ihtiyaç için alternatifler bulmak amacıyla bazı araştırmalar olsa da çoğunlukla buzağı ve fetal sığır gibi hayvanlar kurban edilir. Bunun yanında bir laboratuvarın işletilmesiyle ilgili yakılan fosil yakıt, üretilen sera gazları, tüketilen su ve ağaçları içeren bütün maliyetler ve atıklar da bulunmaktadır. Proje kapsamında kurbansız deri üretimi hedeflense de kurbanlar örtük bir biçimde hala mevcut olarak bulunmaktadır (Catts ve Zurr, 2013b, s. 107).

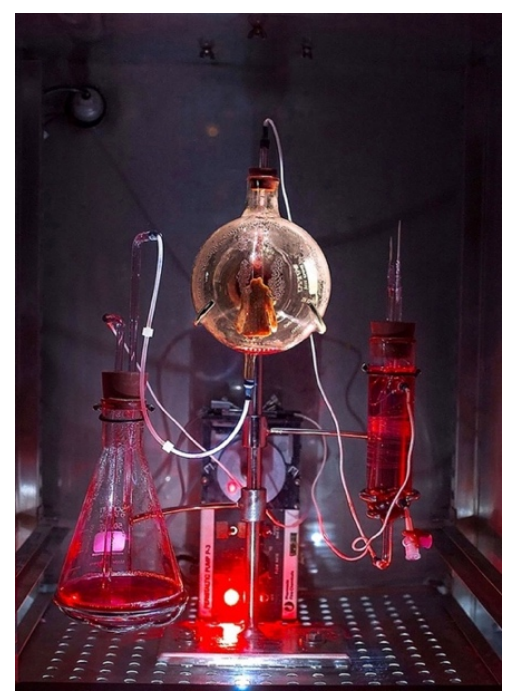

Şekil 3. Victimless Leather, O. Catts, I. Zurr, 2004. 
Catts ve Zurr'un açlklanan iki projesi de hayvanlar ve hayvanlardan elde edilen ürünler üzerine odaklanmıştır. Beslenme ve giyim ihtiyaçları için hayvanlardan elde edilen ürünlerin laboratuvar ortamında üretilmesi denenmiştir. Söz konusu ihtiyaçların canlılara zarar vermeden karşılanması amacını taşıyan bu projeler başarıyla tamamlanmıştır. Ancak Catts ve Zurr, açıklamalarında projelerin gerçekleştirilmesi için üretim aşamasında kullanılan kan plazmasının buzağı ya da fetal sığırdan elde edildiğini ve dolaylı da olsa canlıların zarar gördüğünü belirtmiștir. Ayrıca sanatçıların, enstalasyon ve performans gibi unsurlardan yararlanarak projeleri daha etkileyici bir hale getirdiği söylenebilir. Sonuç olarak biyoteknolojik ve sanatsal kurgu olarak projelerin dikkat çekici olduğu ve hayvanların zarar gördügü her tür uygulamaya yönelik farkındalık sağladığı söylenebilir.

Bir diğer dikkat çeken çalışma ise Heather Dewey Hagborg (2012) tarafından 2012-2013 yılları arasında hayata geçirilen Stranger Vision adlı biyosanat projesidir. Şekil 4 ve 5'te görselleri sunulan proje kapsamında halka açlk yerlerden toplanan genetik materyalin analizlerinden, genetik profillemenin etik sonuçlarını ve biyolojik gözetim kültürü için ortaya çıkan potansiyeli araştıran portreler yapılmıştır. Başıboş saçlar, sigara izmaritleri, çiğnenmiş sakız ve tırnaklarla çalışarak, özel bir yazılım aracılığıyla DNA analiz edilmiştir (Hagborg, 2016, s. 4).

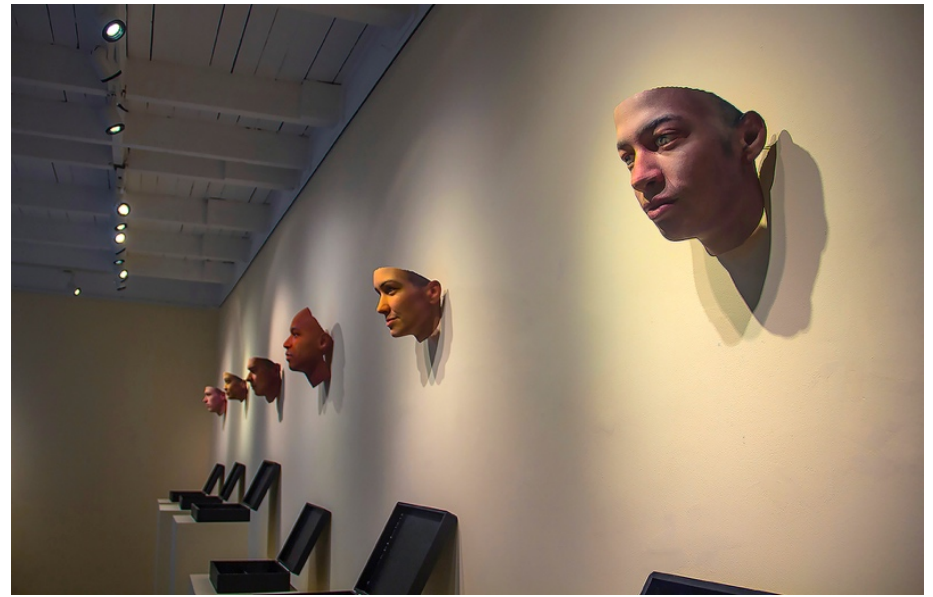

Şekil 4. Stranger Vision, H. D. Hagborg, 2014.

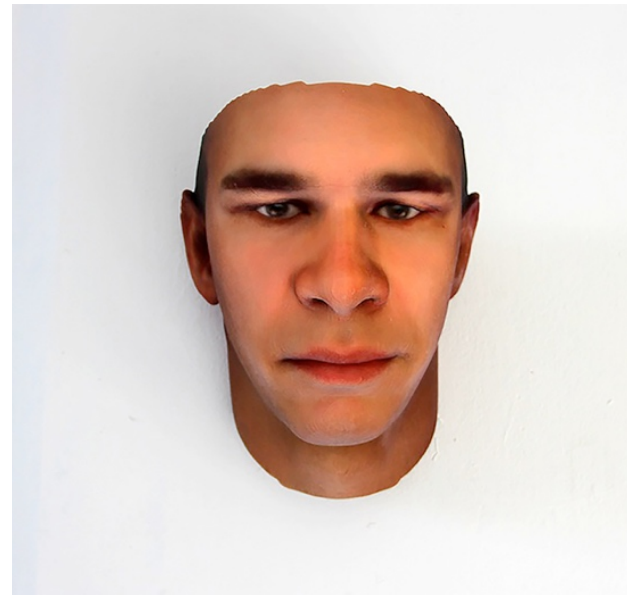

Şekil 5. Stranger Vision, H. D. Hagborg, 2014.

Hagborg, New York'ta Genspace biyoloji laboratuvarında DNA analizlerinde, cinsiyet, ağırlık, yüz şekli, çil ve göz rengi gibi özellikleri ve popülasyonlar hakkında genomik bilgi üretiminin tartışmalı olduğu ve atalarla ilişkilendirilen bölgeleri incelediğini belirtmiştir. Daha sonra, normalde yüz tanıma için kullanılan bir Matlab modeli olan Basel Morphace ile çalışmıştır. Sanatçı, her numunenin yaklaşık beş rastgele varyasyonunu oluşturarak en beğendiğini seçmiștir ve daha sonra gerçek boyutlu, tam renkli bir model oluşturmak için 3 boyutlu baskı yapmıştır (e-flux conversation, 2017). Böylelikle ortaya çıkan bir gözetim biçimi etrafında halka açık bir diyalog oluşturma ve adli tıp örneklerinden görünüm olușturma amacıyla gelişen bir teknoloji sorgulanmıştır (Hagborg, 2016, s. 4). Hagborg'a (e-flux conversation, 2017) göre proje bilinçli olarak tartışma yaratmıştır. DNA fenotipleme araştırması kapalı laboratuvar kapılarının ardında zaten yapılmaktaydı. Sanatçı, projeyi halka açık bir şekilde yaparak bu geleceğin çok yakında olduğunu ve tartışılması gerektiğini insanlara göstermek istediğini belirtmiştir. Ayrıca sanatçı, projenin sanat bağlamından çıkıp sosyal medyada ilgi görerek genetik mahremiyete yönelik halka açık politika toplantılarına konu olmasını ilginç ve şaşırtıcı bulduğunu belirtmektedir.

Hahborg'un bir diğer önemli projesi ise Invisible adını taşımaktadır. Şekil 6'da görseline yer verilen proje, bir önceki Stranger Vision projesinin öne çıkardığı konulara öneriler sunmaktadır. Öyle ki Invisible projesi sanatçının Stranger Vision projesi kitlesel biyolojik gözetleme potansiyeli olan bir çağa girdiğimiz gerçeğini ortaya çıkarmayı amaçlıyorsa, asıl soru şu: bu konuda ne yapabiliriz? sorusu ile başlamıştır. Sanatçı DNA karışımları hakkında yayınlanmış araștırmalardan yararlanarak, DNA izlerini silmek ve örtmek amacıyla kullanılabilecek bir dizi sprey geliştirmek için laboratuarda çalışması sonucunda 2014 yllında Invisible ortaya çlkmıştır. Invisible hayali biyoteknoloji şirketi Biogenfutures tarafından sunulan, bir genetik gizlilik ürünü ve açık kaynaklı protokoller setidir (e-flux conversation, 2017). Invisible, iki tamamlayıcı üründen oluşan bir pakettir. Silme (Erase) spreyi, halka açıkta bıraktığınız DNA'nın \% 99,5'ini siler. Değiştirme (Replace) spreyi ise biyolojik materyali DNA gürültüsüyle gizler. 50'den fazla farklı DNA kaynağından türetilen ve özel bir koruyucu kullanan değiștirme (replace) spreyi, biyolojik gizliliği sağlamaktadır. Invisible, hem çalışan bir ürün hem de bir nesne şeklini alan çok boyutlu bir projedir (Hagborg, 2016, s. 5). 


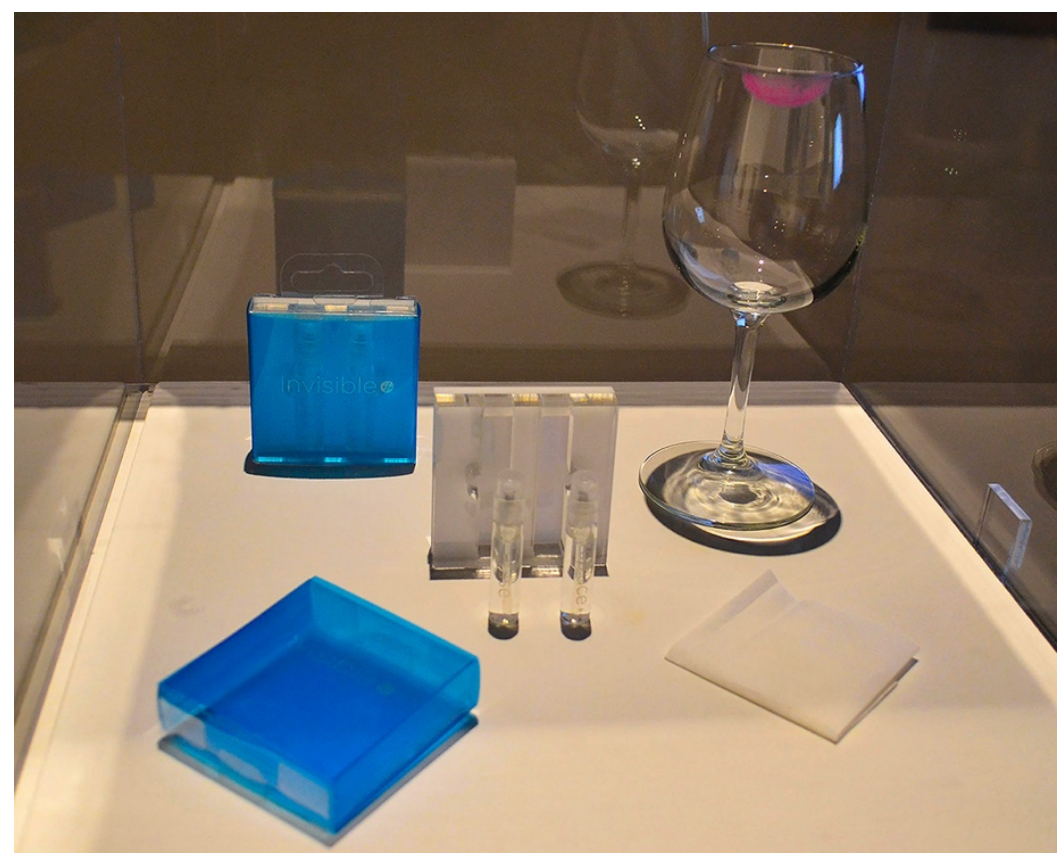

Şekil 6. Invisible, H. D. Hagborg, 2014.

Hagborg, saç teli, sigara izmariti, tırnak ve benzeri gibi genetik materyal izi taşıyan atıklardan insanların kamusal alanda bıraktığı izleri sürerek gerçekleștirdiği Stranger Vision adlı projesinde, DNA fenotip çalışmalarını ve gözetim biçimlerini sorgulamıştır. Genetik mahremiyetin önemine odaklanarak günlük yaşam akışı içinde saç teli ya da çiğnenmiş bir sakız gibi hiç de önemsenmeyen atıklardaki genetik bilginin önemini vurgulamaktadır. Daha da önemlisi DNA fenotipleriyle ilgili bilimsel bir uygulamayı kamuya açı bir şekilde gerçekleştirerek konuyla ilgili bilimsel çalışmalara yönelik büyük bir merakın uyanmasına katkı sağladığı anlaşılmaktadır. Sanatçı, diğer projesinde ise DNA kalıntılarını yok etmeye yönelik bir ürün geliştirmiştir. Böylelikle çalışmalarıyla bilimsel ve sosyal bir gerçekliği tartışmaya açarak kamusal bilinç ve farkındalık gelişimine katkı sağlamıştır.

Biyosanat projeleri, çağın getirdiği teknolojik yeniliklerin ve bilimsel gelişmelerin biyoteknik ve genetik gibi alanlardaki yarattığı yeni olguları ve çoğunlukla bunlara koşut olarak gelişen sorunları ve tartışmaları konu edinmektedir. Biyosanat, insanları, hayvan ve bitki türlerini içine alan tüm canlılara yönelik uygulamaları irdelerken toplumsal ve kültürel değerlerin sorgulanması sürecini de içine alarak bilinç ve farkındalık gelişimini desteklemekte, yeni bakış açısı sunmaktadır.

\section{Selin Balcı ve Ayşe Gül Süter'in Biyosanat Projeleri Üzerine İncelemeler}

Çalışma kapsamında öncelikle biyosanat alanında çalışan ve kendisini disiplinler arası bir sanatçı olarak tanımlayan Selin Balcı'nın çalışmaları incelenmiştir. Selin Balcı, İstanbul Üniversitesi Orman Mühendisliğinden mezun olduğunu, sonrasında $A B D$ 'de çeşitli üniversitelerde mikrobiyoloji laboratuvarlarında araştırmacı olarak çalıştığını, 2008 yılında West Virginia Üniversitesinin Güzel Sanatlar Fakültesi'nde Intermedia Bölümü'nü, 2012 yılında da Maryland Üniversitesinde yüksek lisans eğitimini tamamladığını, bilim ve sanatı harmanlayan çalıșmaların ilgisini çektiğini belirtmiștir (Ünal, 2014). Öncesinde mikrobiyoloji alanında çalışmış olmasının ve laboratuvar teknikleri hakkında bilgi sahibi olmasının yüksek lisans sırasında kendisine büyük avantaj sağladığını da eklemiştir. Genellikle küf mantarları, bakteriler, mikroskobik mantarlar gibi mikroorganizmaları kullanan Balcı, çalışmalarıyla ilgili şu açıklamaları yapmıştır:

Ben disiplinler arası bir sanatçıyım. Projelerim, geleneksel sanat pratiğini bilimsel malzemeler ve küf sporları gibi biyolojik ortamlarla birleştiriyor. Resim yüzeyinde yaşayan organizmaların sonsuz etkileşimlerini, mücadelelerini ve çatışmalarını gözlemlediğim sentetik bir dünya yaratıyorum. Sınırlar, bölümler, kenarlar oluşturmak ve küf büyümesi mecazi olarak insan eylemlerini ve güdülerini temsil etmektedir. 
Sadece küf için bir vivaryum olarak değil, aynı zamanda görünmeyen yaşam formlarının ortaya çıktığı canlı bir stüdyo işlevi gören kâğıdın yüzeyine doğrudan temas ederek fiziksel izler bırakan küf sporlarını kullanıyorum. Aynı zamanda doğal ve yapay olan bu platform, yaratıcı ve küratör olarak hareket ettiğim bir sahne sağlıyor. Geleneksel ortamları oldukça desenli ve renkli küflerle birleştirerek bol görsel ve interaktif biyolojik manzaralar yaratıyorum.

Çalıșmam, yeryüzünde yaşayan, büyüyen, değișen ve ölen tüm organizmaların zamansal doğasını göstermektedir. Aynı zamanda belgelendirmek, korumak ve o belirli zaman dilimi boyunca canlıların tarihsel bir kaydını oluşturmak için bir herbaryum görevi görmektedir. Tamamlandığında, küf mikroskobik dünyadan makroskobik dünyaya geçer. Küf, yalnızca yıkım ve felaket için doğrudan bir metafor haline gelmez; daha çok yeni bir yaşam formuna dönüșür. (Balcl, t.y.-a)

Çalışmalarına ilişkin yaptığı açıklamalarda bilimsel malzemelerle geleneksel sanat pratiklerini birleştirerek küf sporlarının kâğıdın yüzeyine temas etmesiyle biyolojik manzaralar yarattığını ifade eden sanatçı, küfü insanların eylem ve güdülerini temsil eden metafor olarak kullandığını; böylelikle canlılığın doğumdan ölümüne olan seyrine atıfta bulunduğunu belirtmektedir. Sanatçı aynı zamanda çalışmalarının, küf ve benzeri gibi mikroskobik canlıların zaman içindeki tarihsel yolculuğunu kayıt altına alan birer belge olduğunu ifade etmektedir.

Çalışma kapsamında Balcı'nın incelenen ilk projesi 2012 yılında hayata geçirdiği Kontaminasyon Serisi'dir. Balcı, Şekil 7'de görülen Kontaminasyon Serisi'yle ilgili şu açıklamaları yapmıştır:

Kontaminasyon Serisi'nde, her panelin yüzeyi, tüm yüzey kaplanana ve dairesel bordürlerle desenlenene kadar zarif, parlak bir küfle bağlanır. Daha sonra, hem doğal hem de insanlardan etkilenen manzaralarla ilişkilendirilebilecek çeşitli görsel referanslar oluşturmak için küf üretilen bu formları ve şekilleri bir araya getirdim. Formlar, peyzajdaki insan kaynaklı faaliyetlere benzerlik gösteriyor. Bölgeler, sınırlar ve sınır çizgileri yaratırlar ve resmin yüzeyinde çatışmalarla sonuçlanır. (Balcı, t.y.-b)

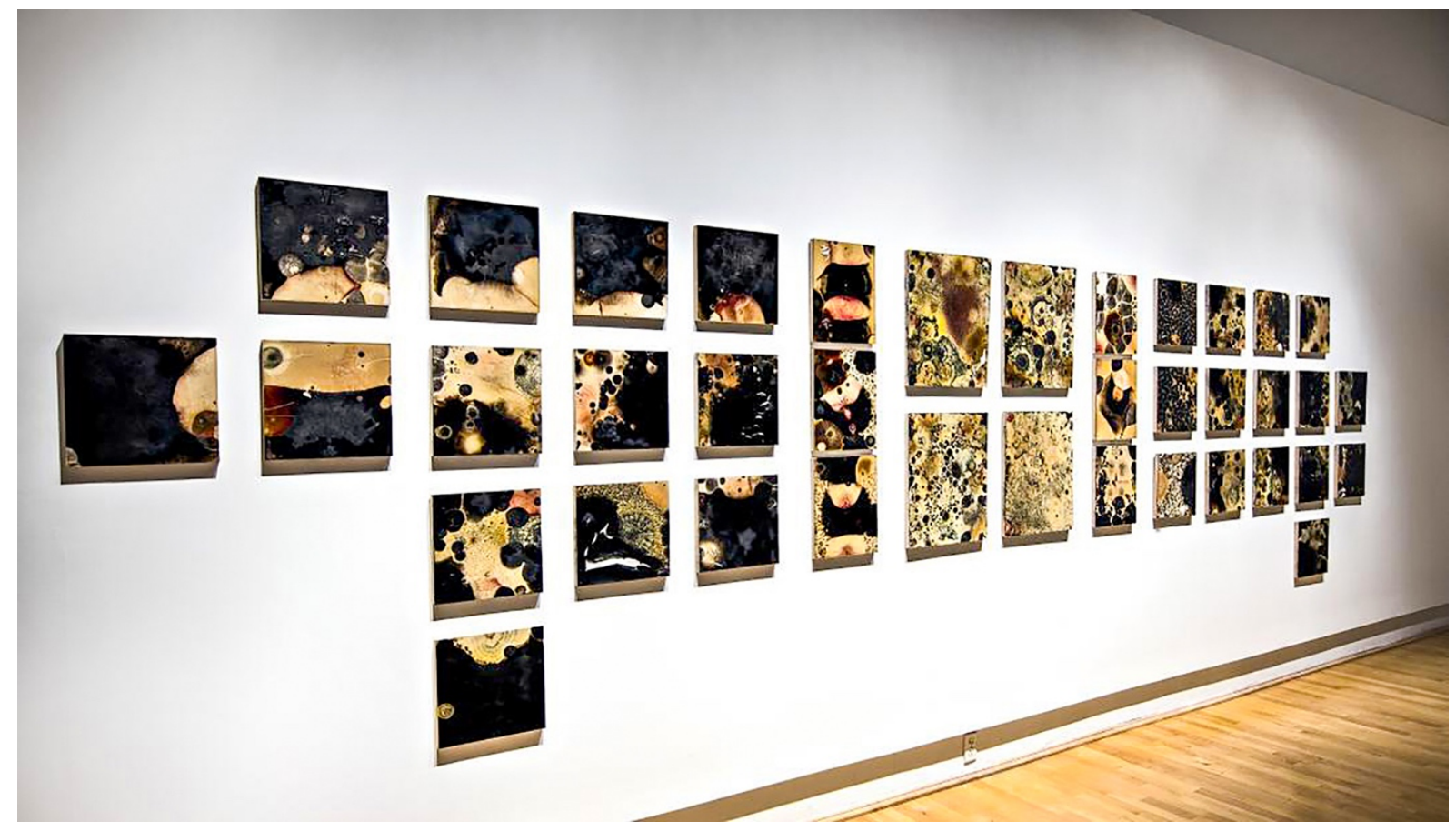

Şekil 7. Kontaminasyon II, S. Balcı, 2012.

Sanatçı projelerine ilișkin açıklamalarında belirttiği gibi küf ile geleneksel sanat formu yaratmıștır. Çalışmalar soyut resim çağrışımı yapmaktadır. Mikroorganizmaların yaşamlarına devam etmek için gerçekleştirdiği aktiviteler, panellerin yüzeyinde farklı desenlenerek çeşitli şekiller yaratmaktadır. Sanatçı farklı biçimlerdeki desenlerin olduğu panelleri kompoze ederek sergi alanına ahenk içinde yerleștirmiştir. 
Sanatçının insanların faaliyetlerine benzettiği küflerin varlıkları ve etkinlikleriyle yarattığı soyut izler estetik bir görüntü yaratırken küf ve insan özdeşiminin biyosanat çalışmalarına kavramsal bir anlam yüklediği söylenebilir. Balcı'nın açıklamalarında da belirttiği gibi mikroorganizmaların yarattığı bölgeler ve sınırlar, insanların bireysel sınırları ve toplumsal yaşam arasındaki ilişkileri, buna bağlı olarak da birlikte yaşama kültürünü hatırlatmaktadır. Sonuç olarak sanatçının küflerden oluşan mikroorganizmaların canlılığını sürdürmek için yaptığı biyolojik faaliyetlerden yola çıkarak yaşamsal güdülerin gücüne, insanların kendilerini gerçekleştirmek için yaptığı etkinlikleri ve birbirleriyle etkileşimlerine işaret ettiği söylenebilir.

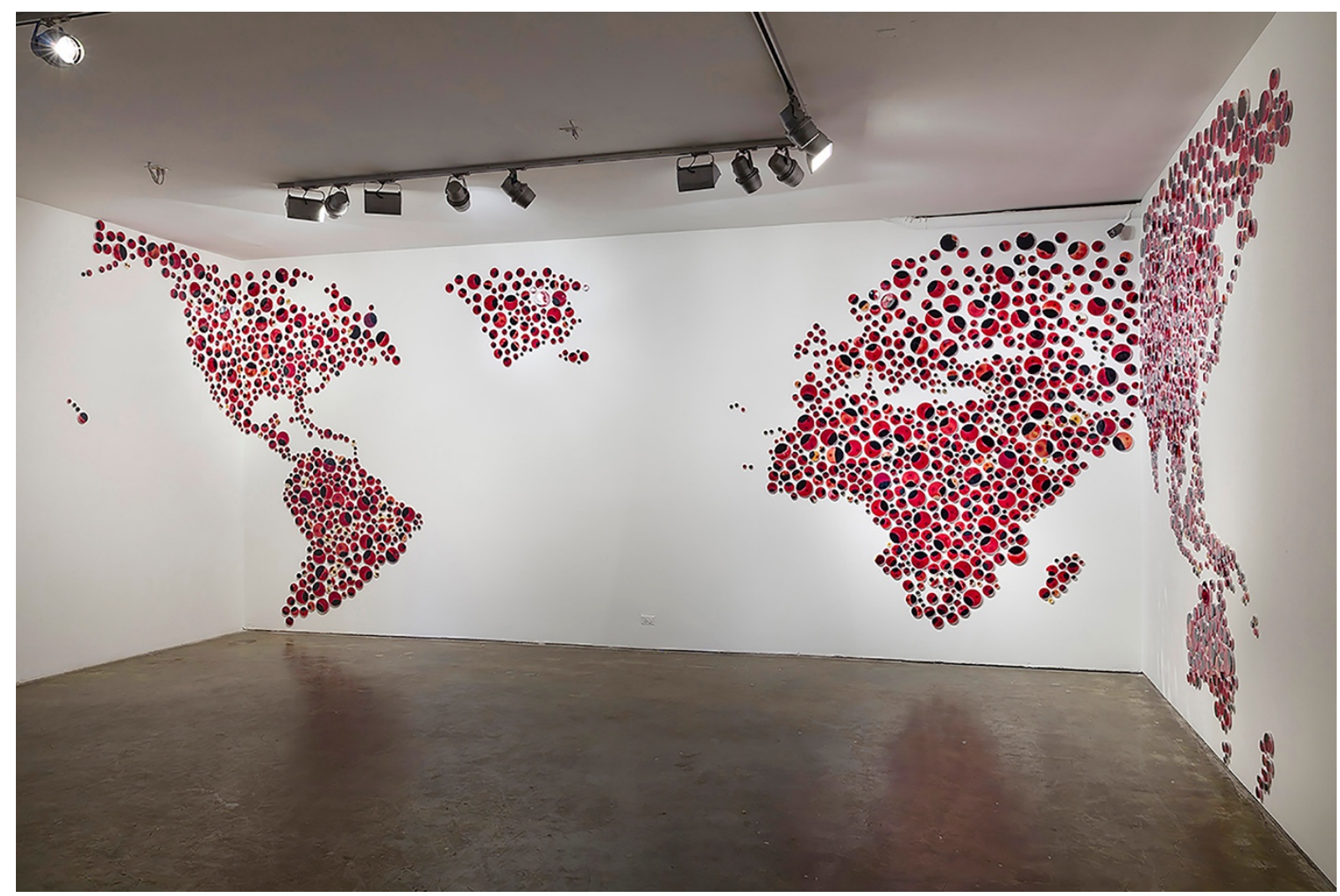

Şekil 8. Bordered World, S. Balcl, 2014.

Balcı'nın bir diğer projesi de 2014-15 yılları arasında hayata geçirdiği petri kaplarında gelişen küf mantarlarından oluşan Bordered World adlı enstalasyonudur. Şekil 8'de görülen çalışmada içerisinde küf mantarları yer alan 2500 petri kabı, sergi alanının duvarlarına dünya haritası biçiminde yerleştirilerek izleyicilere sunulmuştur. Sanatçı, projesiyle ilgili şu açıklamaları yapmıştır:

Bordered World, kaynaklar, bölgesel savaşlar ve canlı organizmalar arasında güç ve kontrol mücadelesi için bir rekabet yaratır. Bu projede, sosyal sorunları anlamak ve vurgulamak için varlığımızın altında yatan sosyal ikilemlere ve ilkelere atıfta bulunuyorum. Kavramlarım, sınırları ve farklı biçimleri ortaya çıkardığı resim yüzeyinde gözlemlenebilen etkileşimleri ve çatışmaları yeniden oluşturmak için mantar ve küf gibi canlı varlıklar kullanılarak keşfedildi. Bordered World'de tüm hayati kaynaklar kısıtlanmıştır. Bu sinırlı ortam, mikropların kaynaklar için rekabet etmesine, belirli bir alana hakim olmasına veya istilacı hale gelerek başkalarını tehlikeye atmasına neden olur. Aynı platformu paylaştıklarında, kaynaklar için bir çatışma ortaya çıkar ve sonunda bu bir sınır çizgisi ile sonuçlanır. Mikroorganizmaların davranışları insan eylemlerine ve güdülerine benzer. Dünya haritasını görsel olarak temsil eden bu mikroplar, savaş ve insani çıkmaz için metafor görevi görür. (Balcl, t.y.-b)

Bordered World projesine ilişkin açıklamalarında belirttiği gibi sanatçı, mikroorganizmaları metafor olarak kullanarak insan ilişkilerine ve sosyal sorunlara atıfta bulunmuştur. Mikroorganizmaların sınırlı kaynakların bulunduğu ortamda canlılığını sürdürme davranışlarıyla insanların güdüleri arasında 
benzeşim kurmaktadır. Sanatçı, insanların ilkel içgüdüleriyle hareket ettiğinde mikroorganizmalarla benzer davranışları göstererek savaş ve insani çıkmazlara neden olduklarına işaret etmektedir. Diğer yandan Balcı'nın Bordered World adını taşıyan enstalasyonuna dikkatlice bakıldığında özdeş petri kaplarının içindeki küflerden oluşan mikroorganizmaların görüntülerinin aynı renklerde ve birbirine benzer biçimlerde olduğu görülmektedir. Sanatçının, küfleri insanları temsil eden birer metafor olarak kullandığı düșünüldüğünde, her bir petri kabının birbirine benzeyen görüntüsü ve dünya haritası gibi anlamlı bir bütün içindeki varlıkları, dünya üzerindeki her bireyin eșit haklara sahip olması gerekliliğini, eșitlik ve evrensellik gibi kavramları akıllara getirmektedir. Böylelikle Bordered World projesinden, insanların ilkel canlılardan farklı olarak sahip olduğu düşünme yetisiyle hareket ettiğinde barış içinde yaşayabileceği ve sosyal sorunlara medeni çözümler bulabileceği anlaşılabilir.

Balcı'nın 2015 yılında hayata geçirdiği bir diğer projesi ise 200 adını taşımaktadır. Bu çalışmasında 200 katılımcı, projeye ilgi duymuş ve gönüllü olarak sanatçıya projesinde kullanması için kendi vücutlarından örnekler vermiştir. Bu örnekler, saç, tırnak, küçük deri parçaları, giysi kumaşları ve ceplerindeki küçük parçalardan sağlanmıștır. Sanatçı katılımcılardan aldığı örnekleri besleyici katkı maddesiyle birlikte petri kaplarına yerleștirmiștir. Katılımcılar isimlerini petri kaplarına tarihleriyle birlikte etiketlemiștir. Birkaç gün sonra katılımcıların vücutlarından paylaştığı parçalardaki mikroorganizmalar petri kabında büyümeye ve her gün form ve renklerini değiştirmeye devam etmiştir. Sanatçı bu yolla katılımcıların geleneksel olmayan yollarla portrelerini yapmayı amaçladığını belirtmiştir (Balcı, t.y.-b).

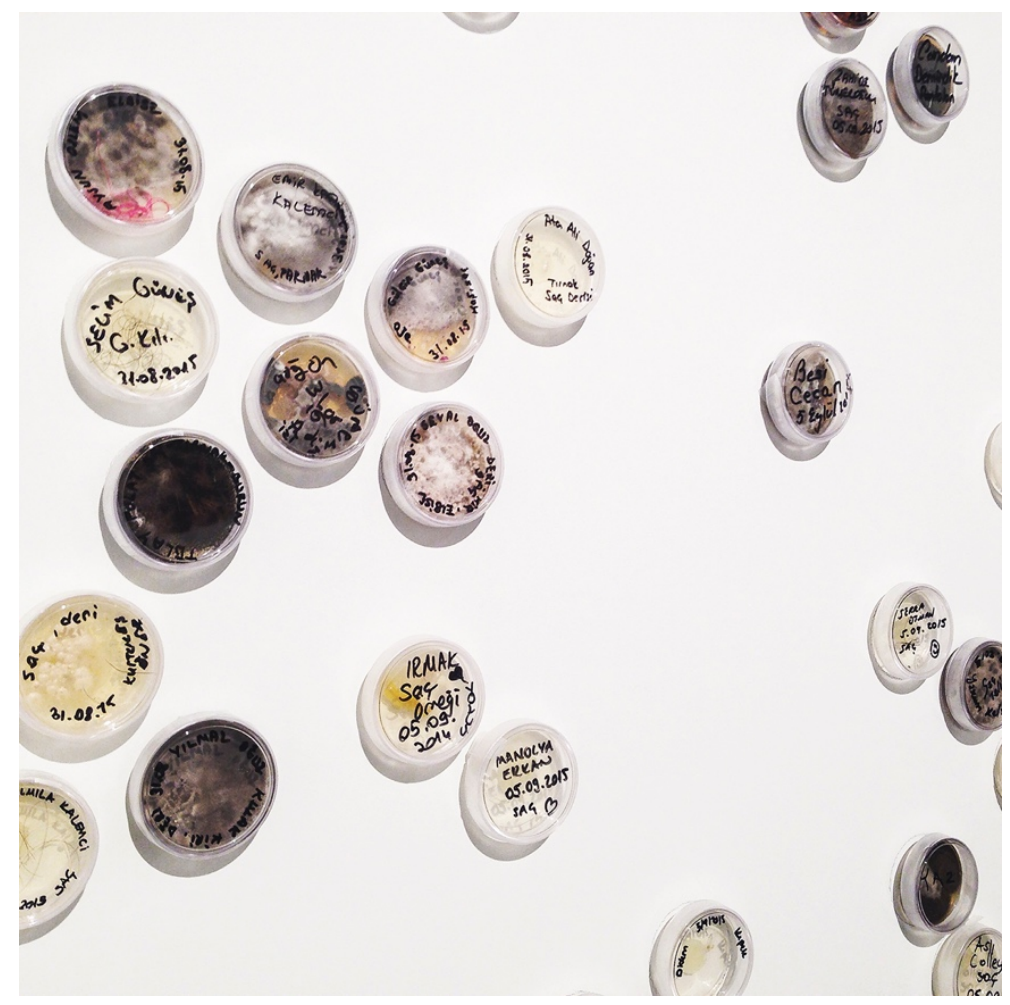

Şekil 9. 200, S. Balcl, 2015.

Balcı, 200 adını verdiği biyosanat projesine katılımcıları dahil ederek interaktif bir hale getirmiștir. Sanatçı gönüllü katılımcıların biyolojik temsilleri olan saç, tırnak, deri parçası gibi örnekleri kimyasal reaksiyona sokarak mikroorganizmalardan elde edilen görsellerle katılımclların bir nevi portresini yapmak istemiștir. Şekil 9'da görüldüğü üzere mikroorganizmaların kimyasal reaksiyonu sonucu birbirinden farklı görüntüler ortaya çıkmıştır. Petri kaplarındaki reaksiyonların her gün form ve renklerini değiștirmesi yaşamsal döngüleri hatırlatmaktadır. Ayrıca Balcı, biyosanat projesini çağdaş sanat pratikleri içerisindeki süreç sanatına dönüștürerek izleyicilerin mikroorganizmaların kimyasal reaksiyonunu takip etmelerini ve izlemelerini sağlamıştır. Projenin katılımcılarla interaktif bir şekilde gerçekleştirilmesi sanatçı ve izleyici etkileşimine olanak sağlamıştır. Katılımcıların mikroorganizmaların kimyasal reaksiyonuna ve oluşum sürecine tanıklık etmesinin biyosanata ve bilime ilgi uyandırdı̆̆ı düşünülmektedir (Balcı, t.y.-b).

Çalışma kapsamında biyosanat projeleri incelenen bir diğer sanatçı ise Ayşe Gül Süter'dir. Süter, New York Üniversitesi Tisch Sanat Okulu'nda animasyon ve dijital sanatlar eğitimi almıștır. Ayrıca sanatçı New York'ta 
bulunan Görsel Sanatlar Okulu'nda resim (2017), yeni medya ve heykel (2013) bölümlerinde misafir sanatçı programlarına katılmıştır. Proje bazında, çeşitli teknikler ve ekipmanlar kullanarak ABD'deki Marine Biyoloji Laboratuvarı'nda (MBL) bilim insanları ile iş birliği yapmakta ve bunları sanatına uyarlamaktadır. Ayrıca Süter, 2018 yılı için Barcelona'da Biyolojik Araştırma Enstitüsü'ne seçilen tek yerleşik sanatçı olmuştur. Sanatçı, algılama ve gerçeklik boyutlarından hareket, ıșık, zaman ve mekân arasındaki ilişkiyi araștırdığını ve bireyin duyusal deneyim süreçlerine odakladığını belirtmiștir. Ayrıca sanatın izleyicilere de sorumluluk verdiğine ve hayatın gerçeklerine karşı sezgileriyle hareket etmeleri gerektiğine inandığını ifade etmiştir (Süter, t.y.-a).

Süter'in sanat anlayışı ve biyosanat projeleriyle ilgili açılklamaları şöyledir:

Geleneksel sanat yapma tekniklerini bilimsel ve teknolojik kavramlarla bütünleștiriyorum. Biyolojik dünyadan ilham alarak, dünyamızın hayal edilemez güzelliği ve çeşitliliği konusundaki farkındalığı artırmayı hedefliyorum. Projelerim biyosanat kavramları ve teknikleri ile ilgilidir. Çok sayıda sanat yapma aracı kullanıyorum ve ayrıca yapay ışık, güneş ışı̆̆ı, kinetik hareketler, bilgisayar tabanlı animasyonlar, kristaller veya bilimsel olarak kullanılan araçları sanatıma dahil ediyorum. (Süter, t.y.-b)

Sanatçı, biyosanat projeleriyle dünyanın güzelliğine ve çeşitliliğine yönelik farkındalığı arttırmak istediğini belirtmiştir. Bilgisayar tabanlı animasyonlardan güneş ışığı ve yapay ışığa kadar birçok araç kullandığını ifade etmiştir. Çalışma kapsamında sanatçının incelenen projelerinin ilki Tear Drop Crystals'dir. Şekil 10'da projeye ait görsel sunulmuştur.

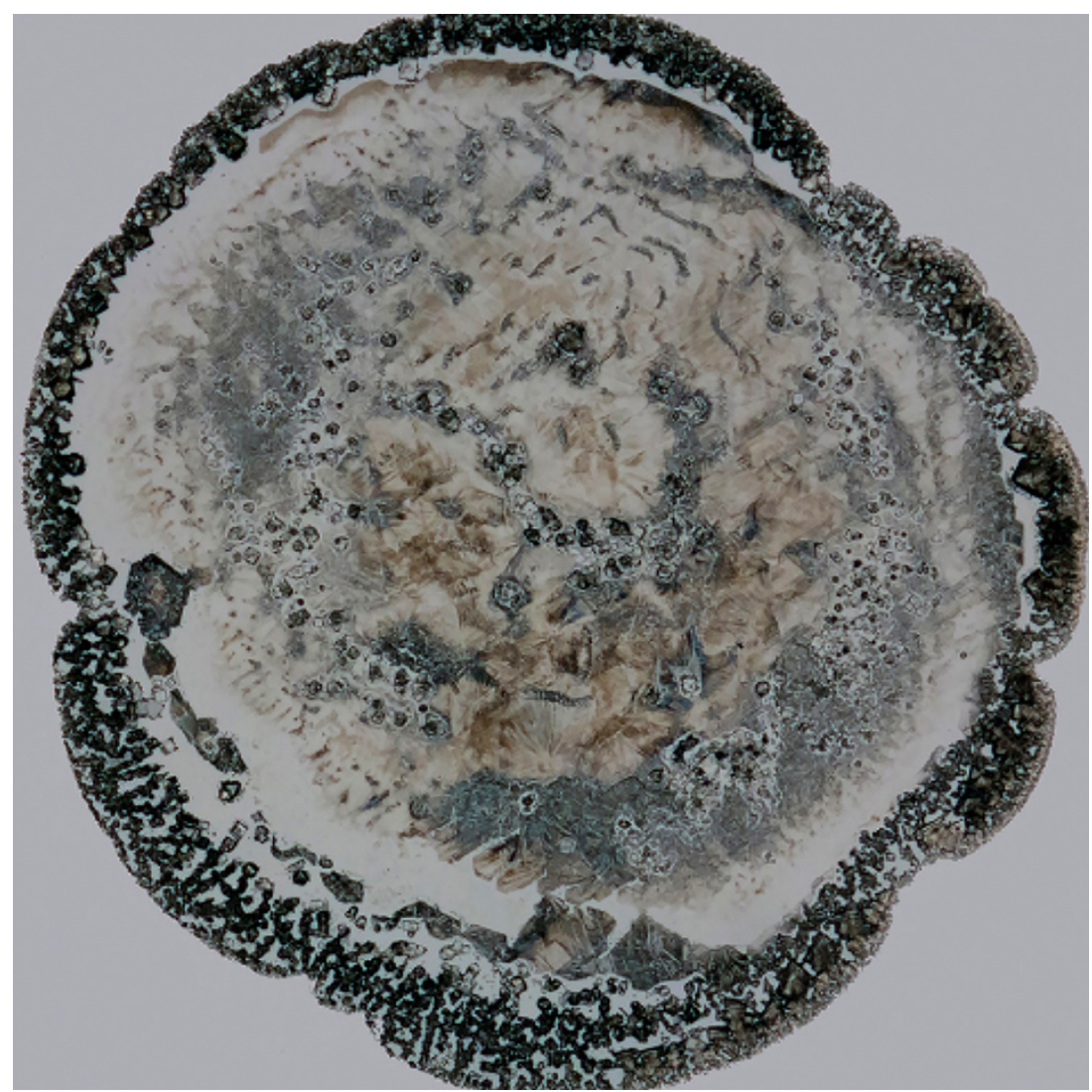

Şekil 10. Tear Drop Crystals, A. G. Süter, 2016.

Sanatçının söz konusu projesine ilişkin açıklamaları şöyledir:

Ağlamak ekzokrin, yani vücuttan bir maddenin çıktığı bir süreçtir. Nefes verme, idrar yapma, dışkılama ve terleme gibi diğer ekzokrin süreçlerde vücut toksik maddeler salgılar. Ağlamanın ve terlemenin vücudun strese tepki olarak ürettiği kimyasalları salgıladığını düşünmek için her türlü neden vardır. Ağladıktan veya terledikten sonra çoğu zaman daha iyi hissediyoruz. Çoğu doğu kültüründe 
erkeklere duygularını ifade etmemeleri öğretilir. Erkeklerin gözyaşlarını toplayarak, petri kaplarının üzerindeki gözyaşlarını kurutmak ve mikroskop altında fotoğraflamak beni bu eserleri yaratmaya yöneltti. Bu, erkeklere bu güzel sanat eserlerini sadece ağlayarak, duygularını ifade ederek yaratabileceklerini kanıtladı. Terledikten sonra buhar halindeki sıvı sayesinde vücudumuzdaki kristallere şahit olabiliriz. Bu kristaller, duygusal veya fiziksel aktivitemizden sonra vücudumuza tepki olarak üretilir. İçgüdüsel davranıșlardır. Bazen bu doğuştan gelen davranışı birçok nedenden dolayı bastırırız. (Süter, t.y.-c)

Ayşe Gül Süter, Tear Drop Crystals projesine ilişkin açıllamalarında da belirttiği üzere erkeklere ait gözyaşlarını petri kaplarında toplayarak kurutmuş ve ortaya çıkan kristalize oluşumların mikroskobik görüntülerini fotoğraflamıştır. Projesinde Doğu kültürlerinde toplumsal baskı sonucunda erkeklerin duygularını rahatlıkla ifade edemediğine dikkat çekerek bu çalışmayı yaptığını belirtmektedir. Süter, klişe haline gelen erkekler ağlamaz söylemine atıfta bulunarak duyguların bir nevi bedenimizde yarattığı fiziksel sonuçlarını görselleștirerek insanların sosyal ve biyolojik yapılarını ilișkilendirmiștir. Ağlamanın sonucunda ortaya çıkan gözyașı kristallerinin sadece biyolojik bir materyal olduğunu; duygusal dışavurumun rahatlatıcı ve kaçınılmaması gerektiğini vurguladığı anlaşılmaktadır. Buna ek olarak sanatçının erkeklerin göz yaşlarını metafor olarak kullanarak mevcut toplumsal cinsiyet rollerinin bireylerin üzerinde oluşturduğu psikososyal etkiye işaret etmektedir. Biyolojik yapı ve olanaklar sosyal yaşantıyı şekillendirdiği kadar, sosyal algılar ve teamüller de biyolojik ve fiziksel tepkiler üzerinde etkili olmaktadır. Sanatçının, Tear Drop Crystals projesiyle biyolojik ve psikososyal oluşumların etkileşimine ilişkin farkındalık gelişimine katkı sağladığı söylenebilir.

Ayşe Gül Süter'in incelenen bir diğer projesi yine kristaller üzerine çalıştığı Crystals In An Artist's Studio adlı biyosanat projesidir. Söz konusu projeye ait görsel, Şekil 11'de görülmektedir.

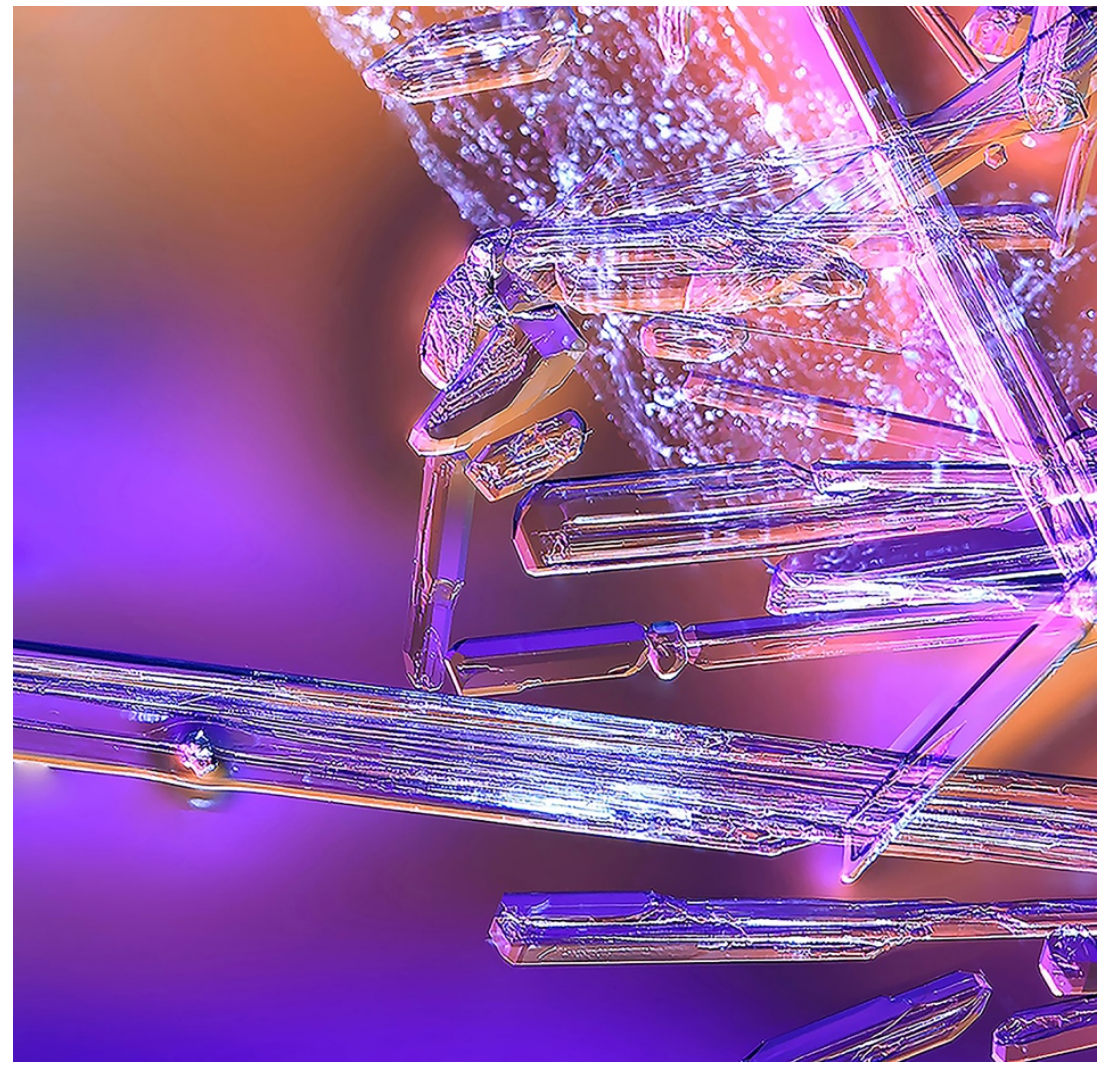

Şekil 11. Crystals In An Artist's Studio, A. G. Süter, 2020.

Sanatçının Crystals In An Artist's Studio projesine ilişkin açıklamaları şöyledir:

Geçtiğimiz yıllarda fen laboratuarlarına misafir sanatçı olarak davet edildim. Orada bilim adamlarının kristalizasyon teknikleriyle deneylerini kanıtladıklarına şahit oldum. Kristalleri düşündüğünüzde, genellikle parlak, 
gösterişli taşlar veya mücevherler aklınıza gelir. Ancak kristal formlar inanılmaz derecede çeşitlidir; vücudumuzda bile bulunabilirler. İster buz kristallerine, buzullara, okyanus kenarı kristallerine, gözyașlarına, ter veya mutfaklarımızdaki tuza bakalım, bunlar mükemmel şekilli doğadan parıltılardır. Onları kendi zevkim için yetiştirmeye başladım, sonra onları sanatıma entegre etmeye başladım. 2020'nin başında sokağa çıkma yasağı zamanlarımızda, bir parti kristal daha yetiștirdim. Her zaman evdeydim, bu yüzden onlara istedikleri hafifliği, karanlığı, sıcaklığı ve huzuru verme şansım oldu. Sonra onları mikroskop ve/veya makro lensli kamera altında fotoğrafladım. Renkler kristallerin hisleridir. Çünkü güneș ışığını kırdıklarında gökkuşağı renklerini dağıtırlar. Bu renkleri elde etmek için mikroskobumun ışığını ayarlıyorum. (Süter, t.y.-d)

Sanatçı söz konusu projesinde kristalizasyon teknikleriyle kristaller tasarladı̆̆ını belirtmektedir. Sanatçı laboratuvar ortamında tasarladığı kristallerden ışık ve renklerin aracılığıyla elde ettiği görüntüleri kayıt altına almıştır. Böylelikle dikkat çeken artistik görseller ortaya çıkmıştır. Projesiyle ilgili açıklamasında buzullar ve okyanus kristalleri gibi doğada bulunan kristallerin yanı sıra ter ve göz yașı kristallerinden de etkilendiğini ifade etmiştir. Görüldüğü gibi çalışma sürecinde kristallerin ışık ve renkle ilişkisi üzerinde duran sanatçı, ışığın kristallerden geçerek kırıldığını böylelikle ışık tayfı oluşturarak gök kuşağı renkleri elde ettiğini ifade etmiştir. Ayrıca ışığı daha etkili kullanabilmek için mikroskobunun ışığında ayarlamalar yaptığını eklemiştir. Sanatçının açıklamalarında da görüldüğü üzere kristal tasarımlarına pandemi ve sokağa çıkma yasaklarının etkilerinin yansıdı̆̆ı düşünülmektedir. Süter'in, pandemi döneminde kristal tasarımına odaklanarak yaşadığı duyguları çalışmalarına yansıttığı söylenebilir. Bir nevi kristaller üzerinde renk ve ışık çalışmaları yaparak renkler aracılığıyla her bir kristal tasarımında farklı duyguyu yansıttığı düşünülebilir.

\section{Sonuç}

Biyosanat canlılığı ve sistemlerini sanatsal olarak ele alan bilimsel ve teknolojik unsurların sanatsal teknik olarak işlev gördüğü bir sanat yaklaşımıdır. İnsanlığı ve diğer bütün canlıları ilgilendiren güncel biyoteknik gelişmelere yönelik sorgulamalarda bulunarak bilinç ve farkındalık yaratmayı hedeflemektedir. Biyosanat projeleri, izleyiciyi canlı materyallerin kullanıldığı bir alana davet ederek etkileyici ve akılda kalıcı özellikler göstermektedir.

Çalışma kapsamında Selin Balcı'nın Kontaminasyon Serisi, Bordered World ve 200 adlı biyosanat projeleri sanatçının açıklamaları doğrultusunda incelenmiştir. Balcı, Kontaminasyon Serisi'nde mikroorganizmalar ile panel yüzeylerinde geleneksel sanat formu yaratmıștır. Mikroorganizmaların canlılığını devam ettirmek için yaptığı biyolojik faaliyetleri insanların etkinlikleriyle özdeşleştirmiştir. Böylelikle sanatçının, canlılığın ve yaşamın gücünü ortaya koyarak birlikte yaşama kültürüne dikkat çektiği söylenebilir. Bir diğer çalışması Bordered World projesinde ise sanatçı, mikroorganizmaların benzer renk ve görüntülerinden oluşan, dünya haritası biçiminde sergilenen özdeş petri kaplarını, insanları temsil eden metafor olarak kullandığını belirterek sosyal sorunlar ve savaşlara atıfta bulunmaktadır. Sanatçının, projesi aracılığıyla insanların ilkel içgüdüsel davranışlarından sıyrılarak paylaşım içinde yaşamayı başarabildiğinde barış ortamının sağlanabileceğine işaret ettiği söylenebilir. Balcı, 200 adını verdiği biyosanat projesini süreç sanatıyla birleştirdiği görülmüştür. Katılımcılardan aldığı saç, tırnak, deri parçası gibi örneklerdeki mikroorganizmalardan kimyasal reaksiyon sonucunda farklı görüntüler ortaya çıkmıştır. Projeyle yaşamsal döngülere işaret edildiği düşünülmektedir. Bunun yanında projenin katılımcılarla yürütülmesinin, izleyici ve sanatçı etkileşimine imkân tanıdığı, böylece bilim ve sanata duyulan duyarlılığı geliştirdiği söylenebilir.

Çalışma kapsamındaki bir diğer sanatçı Ayșe Gül Süter'in ise Tear Drop Crystals ve Crystals In An Artist's Studio adlı projeleri, sanatçının açıllamaları doğrultusunda incelenmiştir. Süter'in incelenen ilk projesi Tear Drop Crystals'dir. Sanatçı, söz konusu proje için erkeklere ait gözyaşlarını kristalize ederek fotoğraflamıştır. Böylelikle erkeklerin göz yaşlarını metafor olarak kullanarak mevcut toplumsal cinsiyet rollerinin bireylerin üzerinde oluşturduğu psikososyal etkiye dikkat çekmektedir. Buna ek olarak sanatçının ağlamanın kaçınılmaması gereken bir duygusal dışavurum olduğunu anlatmak istediği görülmektedir. Süter'in incelenen son projesi ise Crystals In An Artist's Studio'dur. Sanatçı bu projede kristaller tasarlayarak ışık ve rengin kristal üzerindeki görsel etkilerini fotoğraflamıştır. Projeyi pandemi döneminde gerçekleştirdiğini belirten Süter'in, kristallerinde duygularını renk ve ışığın etkileriyle yansıttığı söylenebilir. 
Biyosanat, ülkemizde deneyime yeni açılmış bir sanat pratiği olarak karşımıza çıkmaktadır. Çalışma kapsamında incelenen her iki sanatçının da yurt dışında eğitim aldığı dikkat çekmektedir. Her iki sanatçının da farklı birçok alanda öğrenim görmüş olmasının multidisipliner projeler geliştirebilmelerine katkı sağladığı düşünülmektedir. Daha öncesinde de belirtildiği gibi ülkemizde yaygın olmamasına rağmen biyosanat pratikleri ilgi görmüş, pek çok izleyici projelere ve sergilere ilgi duyarak katılım sağlamıştır. Çalıșmada yer verilen biyosanat projelerinin, biyolojik yapılar ve sosyal davranıșlar gibi pek çok konuda insanların duygusal ve düşünsel dünyasına ayna tuttuğu, biyoteknolojik gelişmelere ilişkin popüler tartışmalara merak uyandırmayı hedeflediği ve farklı bakış açıları sunduğu görülmektedir. Canlılar ve biyolojik materyallerle çalışılan bir sanat pratiği olması, biyosanatı yaşam serüveni devam ettikçe güncelliğini ve önemini koruyacağı ayrıcalıklı bir konuma yerleştirmektedir. Sonuç olarak Sanatsal bakıș açısıyla yaşamın ve bilimsel gerçekliğin kesişiminde yer alan biyosanat projelerinin eleştirel bakışı ve bilimsel okuryazarlığı teşvik edeceği düşünülmektedir.

\section{Kaynakça}

Antmen, A. (2010). 20. yüzyıl batı sanatında akımlar. İstanbul: Sel Yayıncılık.

Atakan, N. (2008). Sanatta alternatif arayıșlar. İzmir: Karakalem Kitabevi.

Balcı, S. (t.y.-a). Statement. Selin Balcı. Erișim adresi: https://selinbalci.com/statement

Balcı, S. (t.y.-b). Selin Balcl, Inter- and multi-disciplinary work. Baker Artist Portfolios. Erişim adresi: https://bakerartist.org/portfolios/selin-balci

Balcı, S. (2012). Kontaminasyon II [Paneller üzerine küf]. Erişim adresi: https://selinbalci.com/mold-onpanel/1/31

Balcl, S. (2014). Bordered World [Enstalasyon]. Erişim adresi: https://selinbalci.com/petri-dishinstallations $/ 1 / 1$

Balcl, S. (2015). 200 [Enstalasyon]. Erişim adresi: https://selinbalci.com/petri-dish-installations/1/30

Byerley, A. ve Chong, D. (2015). Biotech aesthetics: Exploring the practice of bio art. Culture and Organization. 21(3), s. 197-216. doi: 10.1080/14759551.2013.836194

2018, O. ve Zurr, I. (2003). Disembodied Cuisine [Enstalasyon]. The Tissue Culture \& Art Project, Crawley, Australia. Erişim adresi: https://tcaproject.net/portfolio/disembodied-cuisine/

Catts, O. ve Zurr. I. (2004). Victimles Leather [Yarı canlı doku biyosanat yapıtı]. The Tissue Culture \& Art Project, Crawley, Australia. Erişim adresi: https://tcaproject.net/portfolio/disembodied-cuisine/

Catts, 0. ve Zurr I. (2006). Towards a new class o being- the extended body. Artnodes, 6. doi:10.7238/issn.1695-5951

Catts, O. ve Zurr I. (2008). Growing semi-living structures: Concepts and practices for the use of tissue technologies for non-medical purposes. Architechtural Design, 78(6), s. 30-35. doi:10.1002/ad.764

Catts, O. ve Zurr, I. (2013a). The vitality of matter and the instrumentalisation of life. Architectural Design, 83 (1), s. 70-75. doi:10.1002/ad.1527

Catts, O. ve Zurr, I. (2013b). Disembodied livestock: The promise of a semi-living utopia. Parallax, 19(1), s. 101-113. doi: 10.1080/13534645.2013.752062

e-flux conversation. (2017, Şubat 13). Heather Dewey-Hagborg: "Hacking biopolitics". Erişim adresi: https://conversations.e-flux.com/t/heather-dewey-hagborg-hacking-biopolitics/6045

Erçel, S. S. (2019). Çağdaş sanatta alternatif sergi mekanları kullanımı: biyosanat ve biyosanat mekanları üzerine bir irdeleme (Yüksek lisans tezi). İstanbul Teknik Üniversitesi Sosyal Bilimler Enstitüsü, İstanbul.

Hagborg, D. H. (2012). Stranger Vision [Enstalasyon]. Erişim adresi: https://deweyhagborg.com/projects/stranger-visions

Hagborg, D. H. (2014). Invisible [Enstalasyon]. Erișim adresi: https://deweyhagborg.com/projects/invisible

Hagborg, D. H. (2016). Postgenomic identity: art and biopolitic (Doktora Tezi). ProQuest Dissertations and Theses veri tabanından erişildi (UMI no: 10190390). 
Kac, E. (2000). GFP Bunny [Transgenik biyosanat yapıtı]. The Museum Of Modern Art, NewYork, USA. Erişim adresi: https://www.moma.org/calendar/events/6750

Kac, E. (2003). GFP Bunny. Leonardo, 36 (2), 97-102.

Kac, E. (2011). Bio art: From genesis to natural history of the enigma. In O. Grau, and T. Veigl (Eds.), Imagery in the 21st Century (p. 57-80), Cambridge: MIT Press.

Kac, E., Jeantet M. L., Mangin B., Menezes M., Gessert G. ve Vanouse P. (2017). What bio art is: a manifesto. Erişim adresi: http://www.ekac.org/manifesto_whatbioartis.html

Kallergi, A. (2008, Mayıs). Bioart on displaychallenges and opportunities of exhibiting bioart. kallergi.a. Erişim adresi: http://kallergia.com/bioart/docs/kallergi_bioartOnDisplay.pdf

Melkozernov, N. A. ve Sorensen, V. (2020). What drives bio-art in the twenty-first century? Sources of innovations and cultural implications in bio-art/biodesign and biotechnology. AI \& Society, 35(1). doi: 10.1007/s00146-020-00940-0

Mitchell, R. (2010). Bioart and the vitality of media. Seattle: University of Washington Press.

Osborne, P. (2017, 16 Mart). Çağdaş ne zaman başladı? e-skop. Erişim adresi: https://www.eskop.com/skopbulten/cagdas-estetik-cagdas-ne-zaman-basladi/3309

Radomska, M. (2016). Uncontainable life: A biophilosophy of bioart (Doktora tezi, Linköping Üniversitesi). Erişim adresi: https://www.dissertations.se/dissertation/d1cbe3fac1/

Sharma, S. (2014). Bio-art: developing art through bio science. Everyman's Science. 48(6), s. 405-408. Erişim adresi: http://www.sciencecongress.nic.in/pdf/e-book/Feb_March_2014.pdf

Stracey, F. (2009). Bio-art: the ethics behind the aesthetics. Nature Reviews Molecular Cell Biology, 10, s. 496-500. doi:10.1038/nrm2699

Süter, A. G. (t.y.-a). About. Erişim adresi: http://aysegulsuter.net/about/

Süter, A. G. (t.y.-b). Works. Erişim adresi: http://aysegulsuter.net/

Süter, A. G. (t.y.-c). Tear drop crystals. Erişim adresi: http://aysegulsuter.net/portfolio/tear-drops/

Süter, A. G. (t.y.-d). Crystals in an artist's studio. Erişim adresi: http://aysegulsuter.net/portfolio/crystalsin-an-artists-lab/

Süter, A. G. (2016). Tear Drop Crystal [Fotoğraf]. Erişim adresi: http://aysegulsuter.net/portfolio/teardrops/

Süter, A. G. (2020). Crystals In An Artist's Studio [Fotoğraf]. Erişim adresi: http://aysegulsuter.net/portfolio/crystals-in-an-artists-lab/

Thacker, E. (2005). The global genome biotechnology, politics and culture. Cambridge: The MIT Press.

Ünal, G. (2014, Ekim). Mikrorganizmalar sanatla buluştu: Bio-art. Skylife. Erişim adresi: https://www.skylife.com/tr/2014-10/mikroorganizmalar-sanatla-bulustu-bio-art

Vaage, S. N. (2016). Amplifying ambiguities art on fringes of biotechnology (Doktora Tezi, Bergen Üniversitesi). Erişim adresi: https://bora.uib.no/bora-xmlui/handle/1956/12674

Yetişen, A., Davis J., Coşkun F. A., Church M. G. ve Yun H. S. (2015). Bioart. Trends in Biotechnology. 33(12), s. 724-734. doi: 10.1016/j.tibtech.2015.09.011 